\title{
Kajian terhadap Jenis dan Tata Urutan \\ Peraturan Perundang-undangan Indonesia
}

\author{
Syihabudin
}

\begin{abstract}
Kind and procedural regulation of laws managed in determining No. II/MPR/2000 on Law Resource and Procedural regulation of laws contain some problem. Through this discussion, the writer shows some basic problem deals with the kind and procedural regulation of laws. Accordance with the task of the People's Consultative Assembly to criticize the material and the law status of determination of the People's Consultative Assembly (MPR) S) issued sine 1966-2002, The People's Consultative Assembly (MPR) at the General Council 2003, classifies The Determinations into 6 groups, as written in The People's Consultative Assembly Determination No. 1/MPR/2003 on searching the material and law determination status of the People's Consultative Assembly Determination (MPRS) and MPR 1960-2003. The People's Consultative Assembly Determination grouped the Determination No.II/MPR/2003 as a The People's Consultative Assembly Determination valid until Constitution established. The following writing is expected to be material of discussion in forming the Laws as the replacement of The People's Consultative Assembly.
\end{abstract}

\section{Pendahuluan}

Salah satu masalah penting yang menjadi agenda reformasi hukum adalah penataan peraturan perundang-undangan. ${ }^{1}$ Meski kita

telah memiliki beberapa instrumen hukum yang mengatur tentang sistem peraturan perundang-undangan, ${ }^{2}$ tetapi di sana sini kita

1 Jimly Asshiddiqie, "Reformasi Menuju Indonesia Baru: Agenda Restrukturisasi Organisasi Negara, Pembaruan Hukum, dan Keberdayaaan Masyarakat", Makalah disampaikan pada Forum Konggres Mahasiswa Indonesia Sedunia!, Chicago, AS, 2001.

${ }^{2}$ Lihat Tap. MPR No. III/MPR/2000 tentang Sumber Hukum dan Tata Urutan Peraturan Perundangundangan, Kepres No. 188 Tahun 1998 tentang Tata Cara Mempersiapkan Rancangan Undang-Undang dan Kepres No. 44 Tahun 1999 tentang Teknik Penyusunan Peraturan Perundang-undangan dan Bentuk Rancangan Undang-Undang, Rancangan Peraturan Pemerintah, dan Rancangan Keputusan Presiden. 
masih menemui berbagai kerancuan, terutama terkait dengan jenis, lembaga yang berweriang mengeluarkan, serta tata urutannya. ${ }^{3}$

Pada awal Orde Baru, pernah diupayakan penertiban peraturan perundang-undangan, yaitu dengan dikeluarkannya Ketetapan MPRS No. XIX/MPRS/1966 tentang Peninjauan Kembali Produk-Produk Legislatif Negara di Luar Produk MPRS yang tidak sesuai dengan UUD 1945. Bersamaan itu ditetapkan pula Ketetapan MPRS No. XXMPRS/1996 téntang Memorandum DPRGR Mengenai Sumber Tertib Hukum Republik Indonesia dan Tata Urutan Perundang-Undangan Republik Indonesia.

Dalam Ketetapan MPRS No. XX/MPRSi 1996 tersebut ditentukan jenis peraturan perundang-undangan dengan tata urutan: UUD RI 1945, Tap. MPR, UU/Perpu, PP, Kepres, dan Peraturan-Peraturan pelaksana lainnya, seperti Peraturan Menteri, Instruksi Menteri, dan lain-lain.
Menurut Bagir Manan, jenis-jenis peraturan perundang-undangan yang diatur Tap. MPRS di atas ternyata lebih luas daripada yang diatur dalam UUD 1945, tetapi lebih sempit dibandingkan dengan kenyataan yang ada. Dalam praktiknya terdapat peraturanperaturan lain yang tidak disebutkan di atas, khususnya adalah Peraturan Tingkat Daerah. ${ }^{4}$ Di lain pihak; Tap. No. XX/MPRS/1966 juga dianggap berlebihan, karena memasukkan Instruksi 'sebagai salah satu bentuk peraturan perundang-undangan. Instruksi memuat halhal yang konkrit dan individual, sehingga tidak memenuhi esensi peraturan perundangundangan. Karena berbagai kelemahan yang ada pada Tap. tersebut, melalui Pasal 3 Tap. No. V/MPR/1973 tentang Peninjauan ProdukProduk yang Berupa Ketetapan-Ketetapan MPRS RI, ditegaskan bahwa Tap. No. XXI MPRS/1966 "perlu disempurnakan". 5 Tetapi sampai jatuhnya Orde Baru, belum juga dibentuk Ketetapan MPR baru yang menyempurnakannya.

${ }^{3}$ Pada awal kemerdekaan misalnya, kita menemui beberapa bentuk hükum, seperti Maklumat, Surat Edaran, dan'Nota Dinas, yang dianggap mengikat secara hukum. Bahkan melalui produk hukum Maklumat, pemerintah telah mengatur tentang fungsi KNIP sebagai lembaga legislatif sementara dan mengubah sistem pertanggungjawaban kabinet dari Presiden kepadapariemen (sistem pemerintahan parlementer). Lihat Maklumat Wapres No. X; tertanggal 16 Oktober 1945 dan:Maklumat Pemerintah tertanggal 14 Nopember 1945. Demikian halnya, pada masa Orde Lama, berdasarkan Surat Presiden No. 2262/HK/1959 tanggal 20 Agustus 1959 kepada DPRGR, dinyatakan bahwa di samping jenis-jenis peraturan perundang-undangan yang telah disebutkan dalam UUD 1945, yaitu UUD, UU, Perpu, dan PP, dipandang perlu dikeluarkan bentuk-bentuk peraturan lainnya, yaitu: Penetapan Presiden, Peraturan Presiden, Peraturan Pemerintah, Keputusan Presiden, Peraturan Menteri, dan'Keputusan Menteri. Susunan demikian menimbulkan kerancuan dalam praktik ketatanegaraan. Apalagi dalamirealitanya, Penetapan Presiden dan Peraturan Presiden menjadi sangat dominan dan menggantikan kedudukan Undang-Undang.

${ }^{4}$ Bagir Manan, Dasar-Dasar Penundang-Undangan Indonesia (Jakarta: Ind-Hill. Co, , 1992), hilm. 25. Lihat juga A. Hamid S. Attamimi, Peranan Keputusan Presiden Republik Indonesia dalam Penyelenggaraan Pemerintahan Negara (Jakarta: Fakultas Pasca Sarjana Universitas Indonesia, 1990), hllm. 289-291.

${ }^{5}$ Keinginan untuk menyempumakan Tap. No. XXMMRS/1966 tersebut ditegaskan kembali di dalam Tap. No. IXMPR/1978. 
Baru pada masa reformasi, tepatnya pada Sidang Umum Tahun MPR 2000 tuntutan perubahan tersebut direspon oleh MPR dengan mengeluarkan Tap. No. IIIMPR/2000 tentang Sumber Hukum dan Tata Urutan Peraturan Perundang-Undangan. ${ }^{6}$ Pasal 2 Tap. tersebut menetapkan, bahwa tata urutan peraturan perundang-undangan merupakan pedoman dalam pembuatan aturan hukum di bawahnya. Tata urutan peraturan perundang-undangan RI adalah: UUD 1945, Ketetapan MPR RI, Undang-Undang, Peraturan Pemerintah Pengganti Undang-Undang, Peraturan Pemerintah, Keputusan Presiden; dan Peraturan Daerah.

Perumusan mengenai jenis dan tata urutan peraturan perundang-undangan di atas dapat dikatakan kurang sempurna dan mengandung beberapa kelemahan. Jimly Asshiddiqie mencatat setidaknya terdapat empat permasalahan mendasar, yaitu:?

1. mengingat naskah Perubahan UUD sekarang dibuat terpisah, maka seharusnya penyebutan UUD 1945 dilengkapi dengan: "...dan Perubahan UUD";

2. penyebutan Perpu pada nomor urut keempat di bawah UU dapat menimbulkan penafsiran seakan-akan kedudukan Perpu itu berada di bawah UU. Padahal, kedudukan hukum keduanya adalah sederajat.
3. penggunaan nomenklatur Keputusan Presiden yang selama ini dipakai tidak membedakan secara tegas antara keputusan yang mengatur (regeling) dengan keputusan yang bersifat administratif belaka (beschikking);

4. bentuk Peraturan Menteri tidak disebut dalam tata urutan tersebut.

Selain itu, dalam praktik juga masih ditemui berbagai jenis produk hukum yang tidak dikenal dalam sistem peraturan perundang-undangan yang berlaku. MA dan $\mathrm{Bl}$ misalnya, mengeluarkan aturan yang disebut Surat Edaran. ${ }^{8}$ Kemudian beberapa kementerian mengeluarkan peraturan dalam bentuk Keputusan Menteri, sedangkan yang lain menggunakan istilah Peraturan Menteri.

Melalui momen reformasi kiranya penting bagi kita untuk melakukan pembaharuan sistem peraturan perundang-undangan. Peraturan-peraturan yang tumpang tindih dan tidak mengikuti sistem yang baku harus ditertibkan sesuai dengan tingkatan dan derajatnya. Keputusan yang bersifat mengatur (regelling) dan menetapkan (beschikking) harus dibedakan istilahnya. Demikian juga, susunan hirarki peraturan perundangundangan dewasa ini yang dirasakan tidak sesuai lagi dengan perkembangan kebutuhan, perlu segera disempurnakan.

${ }^{6}$ Berdasarkan Tap No. 1/MPR/2003 tentang Peninjauan terhadap Materi dan Status Hukum Ketetapan MPRS dan MPR Tahun 1960-2003, ditentukan bahwa Tap. No III/MPR/2000 digolongkan sebagai Ketetapan MPR yang tetap berlaku sampai dengan terbentuknya UU.

${ }^{7}$ Jimly Asshiddiqie, "Tata Urut Perundang-Undangan dan Problema Peraturan Daerah", Makalah dalam Lokakarya Anggota DPRD se-Indonesia, diselenggarakan oleh LP3HET, Jakarta, 22 Oktober 2000, hlm. 11.

${ }^{8}$ Di samping dalam bentuk Surat Edaran, Mahkamah Agung juga mengeluarkan produk hukum yang bersifat mengatur, yaitu dalam bentuk Peraturan Mahkamah Agung (Perma). 


\section{Istilah dan Pengertian Peraturan . Perundang-Undangan}

Sampai saat ini, belum ada kesepakatan tentang penggunaan istilah peraturan perundang-undangan. Dalam kenyataan, baik dalam naskah perạturan perundang-undangan maupun dalam berbagai literatur Hukum Tata Negara Indonesia, terdapat empat istilah yang sering ditemui dalam menyebut peraturan perundang-undangan, yaitu: pertama, peraturan negara; kedua, peraturan perundangan; ketiga, perundang-undangan; dan keempat, peraturan perundang-undangan

Dalam bahasa Belanda, dikenal istilah wet, wetgeving, wettelijke regels atau wettelijke regeling(en). ${ }^{9}$ Istilah wet sendiri dibedakan.. antara wet in formele zin (undang-undang dalam arti formal) dan wet in materiele zin (undang-undang dalam arti material)). Istilah perundang-undangan dan peraturan perundangundangan berasal dari istilah wettelijke regels. Sedangkan istilah peraturan negara mungkin merupakan terjemahan dari staatsregeling. ${ }^{10}$

Istilah peraturan negara dipergunakan oleh Solly Lubis. Lubis juga mempergunakan istilah peraturan perundang-undangan dan per- undang-undangan; tetapi yang dimaksudkan dari kedua istilah ini adalah peraturan mengenai tatacara pembuatan. peraturan negara. Sedangkan bila yang dimaksudkan adalah peraturan yang dilahirkan dari perundang-undangan, disebut peraturan (negara) saja."

Soehino menggunakan istilah peraturan perundangan. ${ }^{12}$ Istilah ini pernah dipergunakan dalam Tap. MPRS No. XXIMPRS/1966 sebagaimana tercantum dalam judul ketetapan tersebut, yaitu "Sumber Tertib Hukum Republik Indonesia dan Tata Urutan Peraturan Perundangan Republik Indonesia" (cetak miring oleh penulis).

Istilah perundang-undangan terdapat pada dua konstitusi yang pernah berlaku di Indonesia, yaitu terdapat pada judul Bagian 2 BAB IV Konstitusi RIS 1949 dengan rumusan "perundang-undangan" dan dalam judul Bagian II BAB III UUDS 1950 dengan rumusan yang sama. Istilah perundang-undangan ini di antaranya dipergunakan oleh Irawan Soejito ${ }^{13}$ dan Amiroeddin Syarif. ${ }^{14}$

Adapun istilah peraturàn perundangundangan di antaranya dipergunakan oleh $\mathrm{A}$.

${ }^{9}$ Rosjidi Ranggawidjaja, Pengantar'llmu Perundang-undangan Indonesia(Bandung: MandarMaju, 1998), him. 15 .

${ }^{10} \mathrm{lbid}$. , hlm. 16. hlm. 1-2.

"M. Solly Lubis, Landasan dan Teknik Perundang Undangan, Ctk III, (Bandung: Mandar Maju, 1989),

${ }^{12}$ Soehino, Hukum Tata Negara, Teknik Perundang-Undangan, Edisi Kedua, Ctk. Ketiga, (Yogyakarta: Liberty, 2003), hlm. 1. Dalam buku lainnya yang diterbitkan tahun 1997, Soehino menyebut istilah "peraturan perundang-undangan". Lihat Soehino, Hukum Tata Negara, Penyusunan dan Penetapan Peraturán Daerah (Yogyakarta: Liberty, 1997), hlm. 1.

${ }^{13}$ Irawan Soejito menyebut adanya pérundang-undangan negara dan perundang-undangan daerah. Lihat, Irawan Soejito, Teknik Membuat Undang-Undang, Ctk. Kelima, (Jakarta: Pradnya Paramita, 1993), hlm. 6.

${ }^{14}$ Amiroeddin Syanif, Penundang-Undangan, Dasar, Jenis, dan TeknikMembuatnya, Ctk. Kedua, (Jakarta: Rineka Cipta, 1997), hlm. 5. 
Hamid S. Attamimi, R. Sri Soemantri $M{ }_{1}{ }^{15}$ Bagir Manan, ${ }^{16}$ Maria Farida Indrati Soeprapto, ${ }^{17}$ dan Djoko Prakoso. ${ }^{18} \mathrm{Di}$ samping itu, istilah ini juga dipergunakan dalam Tap. №. III/MPR/2000, UU No. 5 Tahun 1956 tentang Peradilan Tata Usaha Negara, dan peraturan perundangundangan lainnya.

Dewasa ini, banyak dipergunakan istilah yang terakhir ini, yaitu peraturan perundangundangan. Menurut Attamimi istilah ini berasal dari istilah dalam bahasa Belanda, yaitu"wettelijke regelingen, ${ }^{19}$ yang berarti peraturan-peraturan yang bersifat perundang-undangan ${ }^{20}$ atau peraturan perundang-undangan. ${ }^{21}$

Menurut Rosjidi Ranggawidjaja, istilah di atas tidak mutlak dipakai secara konsisten, 'karena dalam konsteks tertentu lebih tepat dipergunakan istilah perundang-undangan dan dalamkonteks lain digunakan istilah peraturan perundang-undangan ${ }^{22}$ Penggunaan istilah "peraturan perundang-undangan" lebih berkaitan atau lebih relevan dalam pembicaraan mengenai jenis atau bentuk peraturan (hukum). Dalam' konteks lain lebih "kena" dipakai istilah perundang-undangan saja, misalnya istilah Ilmu Perundang-Undangan, Teori PerundangUndangan, Dasar-Dasar Perundang-undangan, dan sebagainya. ${ }^{23}$

1 Penulis sendiri berpendapat, bahwa istilah peraturan negara dan peraturan perundangan tidak tepat. Peraturan negara cakupannya terlalu luas, dan bahkan bisa menyangkut pada peraturan kebijaksanaan (beleidsregels) yang dikeluarkan pejabat tata usaha negara melalui freies ermessen. Sedangkan penggunaan istilah peraturan perundangan tidak tepat; karena kata wet pada umumnya diterjemahkan dengan "undang-undang dan bukan "undang". ${ }^{24}$

${ }^{15}$ R. Sri Soemantri, M., Hak Uji Material di Indonesia, Edisi Kedua, (Bandung: Alumni, 1997), hlm. 6.

${ }^{16}$ Bagir Manan, op.cit., hlm. 1. Bagir Manan menyamakan istilah peraturan perundang-undangan dengan istilah undang-undang dalam artimateriel. Ibid., him. 3.

${ }^{17}$ Menurut Maria Farida, peraturan perundang-undangan adalah terjemahan dari istilah Belanda wettelijke regeling. Kata wetumumnya diterjemahkan dengan "undang-undang". Sehubungan dengan kata dasar "undangundang', maka terjemahan wettelijke regeling adalah peraturan perundang-undangan. Maria Farida Indrati Soeprapto, IImu Perundang-Undangan, Dasar dan Pembentukannya (Yogyakarta: Kanisius, 1998), h/m. 53.

${ }^{18}$ Djoko Prakoso, Proses Pembuatan Peraturan Daerah (Jakarta: Ghalia Indonesia, 1985), him. 9.

${ }^{19}$ A. Hamid S. Attamimi, op.cit, him. 200.

${ }^{20}$ Rosjidi Ranggawidjaja, Pedoman Teknik Perancangan Peraturan Perundang-Undangan (Bandung: CitaBakti Akademika, 1996), h/m.7.

${ }^{21}$ A. HamidS. Attamimi, loc.cit.

${ }^{22}$ Rosjidi Ranggawidjaja, Pengantar ...op.cit., him. 17.

${ }^{23} \mathrm{lbid}$, hlm. 17. A. Hamid S. Attamimi membagi Ilmu Pengetahuan Perundang-undangan (Gesetzgebungswissen-schaff) menjadi dua, yaitu Ilmu Perundang-undangan (Gezetzgebungsiehre) dan Teori Perundang-undangan (Gesetsgebungstheorie). Lihat, A. Hamid S. Attamimi, "Teori Perundang-undangan Indonesia, Suatu Sisi ilmu Pengetahuan Perundang-undangan Indonesia yang Menjelaskan dan Menjemihkan Pemahaman," Pidato Pengukuhan Jabatan Guru Besar Tetap pada Fakultas Hukum Universitas Indonesia, 25 April 1992, hlm. 18-19.

${ }^{24}$ Menurut Maria Farida, keberatan terhadap istilah "peraturan perundangan" sebagai terjemahan wettelijke regeling ialah karena arti kata "undang" dewasa ini tidak mempunyai kaitan dengan pengertian hukum, kecuali 
Oleh karena itu, penulis sependapat dengan Rosjidi Ranggawidjaja bahwa baik pengertian perundang-undangan maupun peraturan perundang-undangan keduanya merupakan istilah yang tepat sebagai terjemahan dari wettelijke regeling. Namun demikian; untuk menjaga konsistensi penggunaan istilah, penulis lebih memilih menggunakan istilah peraturan perundang-undangan, dengan alasan: (1) istilah ini secara resmi dipergunakan oleh Tap. No. III/MPR/2000 dan beberapa peraruran perundang-undangan lainnya; dan (2) istilah ini banyak dipergunakan oleh ahli Hukum Tata Negara, seperti R. Sri Soemantri, Bagir Manan, A. Hamid S. Attamimi, Maria Farida Indratij Soeprapto, Rasjjdi Ranggawidjaja, dan lain-lain.

Dari beberapa pengertian peraturan perundang-undangan yang dikemukakan oleh para ahli, dapat diidentifikasi sifat-sifat dan ciriciri dari suatu peraturan perundang-undangan, yaitu: ${ }^{25}$

a. peraturan perundang-undangan berupa keputusan tertulis, jadi mempunyai bentuk dan atau format tertentu;

b. dibentuk, ditetapkan, dan dikeluarkan oleh pejabat yang berwenang, baik di tingkat pusat maupun di tingkat daerah. Pejabat yang berwenang, maksudnya adalah pejabat yang ditetapkan berdasarkan - ketentuan yang berlaku berdasarkan atribusi maupun delegasi;

c. peraturan perundang-undangan tersebut berisi tigkah laku. Jadi, peraturan perundang-undangan bersifat mengatur (regulerend), tidak bersifat sekali sejalan (einmahlig); dan

d. peraturan perundang-undangan mengikat secara umum (karena ditujukan kepada umum), artinya tidak ditujukan kepada orang atau individu tertentu (tidak bersifat individual).

Berdasarkan pada ciri-ciri di atas, penulis mendefinisikan peraturan perundangundangan sebagai berikut: "Setiap keputusan tertulis yang dibentuk, ditetapkan, dan dikeluarkan oleh pejabat atau lingkungan jabatan yang berwenang yang berisi aturan tingkah laku yang bersifat atau mengikat secara umum (berdaya laku ke luar) dan berlaku terus menerus (daurhaffig). ${ }^{n 6}$

\section{Jenis Peraturan Perundang-Undangan Indonesia}

Kehadiran Tap. No. III/MPR/2000 tentang sumber Hukum dan Tata Urutan Peraturan Perundang-undangan yang menggantikan kedudukan Tap. No. XXMPRS/1996 diharapkan mampu menertibkan sistem hukum Indonesia pada umumnya dan sistem peraturan perundang-undangan Indonesia pada khususnya. ${ }^{27}$

dan dilakukan dengan cara yang khusus pula, yang apabila tidak demikian, peraturan itu kehilangan kekuatan mengikatnya (afkondiging, promulgation). Maria Farida Indrati Soeprapto, op.cit., hlm. 53. Lihat Juga, A Hamid S. Attamimi, Peranan Keputusan Presiden ...op.cit., him. 200.

${ }^{25}$ Rosjidi Ranggawidjaja, Pengantar Ilmu....op.cit., hlm. 19-20.

${ }^{26}$ Maksud dari daurhaftig.(berlaku terus menerus) adalah kebalikan dari keputusan :tertulis yang berlaku sekali selesai (einmahlig).

${ }^{27}$ Tap. No. III/MPR/2000 yang terdiri dari 8 pasal mengatur materi muatan yang padat, yaitu: (a) pengertian dan status sumber hukum (Pasal 1 ayat (1), (2), dan (3)); (b) jenis peraturan perundang-undangan beserta 
Dalam kenyataannya, Tap. yang diharapkan mampu menciptakan tertib peraturan perundang-undangan ini malah sebaliknya, mengandung berbagai macam kerancuan, yang menyebabkan kekacauan di dalam sistem peraturan perundang-undangan Indonesia. Beberapa masalah yang muncul itu terkait dengan pengertian sumber hukum, jenis peraturan perundang-undangan, hirarki peraturan perundang-undangan, dan pengujian peraturan perundang-undangan. ${ }^{28}$ Beberapa masalah yang penulis temui di dalam Tap. tersebut terkait dengan jenis peraturan perundang-undangan adalah:

\section{UUD 1945 dan "Perubahan" UUD}

Di dalam Tap. No. Ill/MPR/2000 dijelaskan bahwa UUD merupakan hukum dasar tertulis negara Republik Indonesia, memuat dasar dan garis-garis besar hukum dalam penyelenggaraan negara. Dalam pembahasan rancangan UUD selama sidang-sidang BPUPKI tahun 1945, UUD dipahami sebagai tertulis dari hukum dasar yang mengatur masalah-masalah pokok dalam bernegara. pengertian ini kemudian tertuang dalam Penjelasan UUD 1945. Pengertian yang sama diulang di dalam Tap. No. XXIMPRS/1966. Pengertian UUD tersebut tampak dangkal, terutama jika memperhatikan isi dan fungsi UUD $1945 .{ }^{29}$ Menurut berbagai kajian, isi konstitusi atau UUD meliputi cita-cita bernegara, jaminan terhadap hak-hak asasi manusia dan warga negara, struktur organisasi negara, serta pembagian dan pembatasan tugas ketatanegaraan yang juga bersifat fundamental, ${ }^{30}$

Pada awal reformasi, ketika muncul tuntutan yang demikian kuat dari masyarakat untuk merubah UUD 1945, muncul permasalahan bagaimanakah cara atau bentuk perubahannya? Apabila perubahan UUD ditetapkan dengan dengan produk hukum berupa Ketetapan MPR, padahal dalam tata urutan perundang-undangan ditentukan bahwa Ketetapan MPR itu lebih rendah kedudukannya daripada UUD, maka bagaimana mungkin perubahan terhadap UUD dituangkan dalam perundang-undangan yang derajatnya lebih rendah? Baik UUD maupun Tap. MPR memang merupakan produk hukum

pengertian masing-masing (Pasal 2 dan pasal 3 ayat (1) sampai ayat (7)); (c) hirarki peraturan perundangundangan dan prinsip-prinsipnya; Pasal $2 \mathrm{jo}$. Pasal 4 ayat (1); (d) pengaturan tentang lembaga-lembaga lain dalam konteks hirarki hukum (Pasal 4 ayat (2)); dan (e) pengujian terhadap keabsahan peraturan perundangundangan (Pasal 5 ayat (1), (2), (3), dan (4)).

${ }^{28}$ Mengingat banyaknya permasalahan di dalam Tap tersebut, Fajul Falaakh memasukkan Tap. itu ke dalam salah satu produk MPR paska Pemilu 1999 yang bermasalah. Menurut Fajul Falaakh, Tap ini tidak termasuk dalam dokumen amandemen konstitusi, tetapi isinya telah banyak mengubah konstitusi. Ketetapan yang dihasilkan bersamaan Perubahan Kedua UUD 1945 ini tidak disebut oleh MPR sebagai amandemen konstitusi, tetapi telah mengacaukan UUD 1945 dan kedua perubahannya. Mohammad Fajul Falaakh, et, al., Laporan Akhir Kajian tentang Peninjauan terhadap Materi dan Status Hukum Ketetapan MPRS dan MPR Tahun 1960-2002 (Yogyakarta: Kerjasama Setjen MPR-RI dengan UGM, 2003), hlm. 38.

${ }^{29} \mathrm{lbid.}, \mathrm{hlm}$. 40-41.

${ }^{30}$ R. Sri Soemantri M., Prosedur dan Sistem Perubahan Konstitusi (Bandung: Alumni, 1987), him. 48-51. 
$M P R$, tetapi karena nama yang diberikan kepada produk itu berbeda, tentunya derajatnya pun berbeda, ${ }^{31}$ sehingga Tap. MPR tidak bisa dipergunakan untuk merubah UUD.

Untuk itu, maka kemudian diperkenalkan bentuk hukum yang sama sekali belum dikenal dalam sistem peraturan perundang-undangan Indonesia, yaitu bentuk "perubahan" atau "amandemen" UUD..$^{32}$ Dengan demikian akan terdapat perubahan pertama, kedua, ketiga, dan seterusnya. Oleh karena itu, dalam jenisjenis peraturan perundang-undangan perlu dicantumkan secara tegas bentuk "Perubahan UUD" yang sederajat dengan UUD, sehingga jenis peraturan perundang-undangan yang pertama ialah "UUD 1945 dan Perubahan UUD".

\section{Ketetapan MPR}

Ketetapan MPR mulai dikenal sejak sidangsidang MPRS tahun 1960..33 Keberadaan Ketetapan MPR didasarkan pada dua hat: 34

a. Ketentuan-ketentuan yang tersirat dalam UUD 1945.35

b. Praktik ketatanegaraan atau kebiasaan ketatanegaraan. Praktik atau kebiasaan ketatanegaraan merupakan salah satu sumber Hukum Tata Negara.dan terdapat pada setiap negara.

Dalam kenyataannya, Tap MPR(S) memiliki peranan yang penting dalam kehidupan ketatanegaraan Indonesia. Terbukti, Tap. MPR telah mengatur berbagai masalah penting, termasuk di dalamnya mengatur materi muatan konstitusi. ${ }^{36}$ Semenjak 1960 sampai

${ }^{31}$ R. Sri Soemantri M., UUD 1945, Kedudukan dan Aspek-Aspek Perubahannya (Banding: UnpadPress, 2002), hlm. 8.

${ }^{32}$ Dari kajian yang dilakukan oleh R. Sri Soemantri M., terdapat dua macam sistem perubahan konstitusi, yaitu sistem Perancis dan sistem Amerika Serikat. Menurut sistem Perancis, apabila sebuah UUD diubah, yang akan diajukan sebagai usul perubahan dan yang akan diberlakukan ialah UUD yang baru yang telah diubah. Hal ini berbeda dengan sjstem Amerika Serikat, di mana menggunakan sistem amandemen (perubahan). Agar perubahan itu merupakan satu rangkaian kesatuan dengan UUD yang diubah, maka perubahan sebagai "bentuk" dilampirkan pada UUD tersebut. Ibid., hlm. 18-20. Lihatjuga R. Sri Soemantri M., Prosedur dan Sistem ...op.cit., hlm. 92-107. Sistem Perancis pernah digunakan dilndonesia, yaitu ketika berlakunya Konstitusi RIS 1949. Menurut ketentuan dalam konstitusi, UUD RIS dapat diubah dengan Undang-Undang Federal yang dibentuk oleh Pemerintah bersama-sama dengan DPR dan Senat.

${ }^{33}$ Sebelum terbentuk MPR sebagai hasil Pemilihan Umum, disebut Tap. MPRS.

${ }^{34}$ Bagir Manan, op.cit, hlm. 32. Perhatikan juga R. Sri Soemantri M., Ketetapan MPR(S) sebagai Salah Satu Sumber Hukum Tata Negara (Bandung: Remaja Karya, 1988), hlm. 30-31.

${ }^{35} \mathrm{MPR}$ menurut UUD 1945 mempunyai berbagai wewenang untuk melakukan tindakan atau membuat keputusan hukum seperti menetapkan GBHN, memilih dan mengangkat Presiden dan Wakil Presiden, serta mengubah UUD 1945. Keputusan-keputusan hukum ini harus diberi bentuk hukum tertentu. Keputusan MPR diberi nama ketetapan didasarkan pada bunyi Pasal 3 UUD 1945: "MPR menetapkan Undang-Undang Dasar dan Garis-Garis Besar daripada Haluan Negara". Karena "menetapkan", makabentuknya diberi nama Ketetapan.

${ }^{36}$ Sebagai contoh adalah Tap. No. IVIMPR/1983 tentang Rerendum. Tap. ini telah dicabut dengan Tap. No. VIII/MPR/1998. 
dengan Sidang Umum Tahunan (SUT) MPR 2002, MPR telah mengeluarkan KetetapanKetetapan MPR(S) sebanyak 139 Ketetapan $\operatorname{MPR}(S) .^{37}$

Banyaknya Ketetapan MPR tersebut tidak terlepas dari luasnya wewenang yang dimiliki oleh MPR sebelum amandemen UUD 1945. Wewenang tersebut bersumber dari Pasal 1 ayat (2), Pasal 3, Pasal 6 (2) UUD 1945, dan Penjelasan Umum UUD 1945 tentang Kedaulatan Rakyat. Berdasarkan ketentuan tersebut, MPR berwenang untuk mengeluarkan Ketetapan sebagai berikut: ${ }^{38}$ (a) Ketetapan yang bersifat mengatur sekaligus perintah kepada Presiden; (b) Ketetapan yang bersifat beschikking; dan (c) Ketetapan yang mengatur ke dalam (interne regelingen);

Dalam perkembangannya, kewenangan MPR untuk mengeluarkan Tap, tersebut meluas, dan meliputi juga: (d) Ketetapan yang bersifat deklaratoir; (e) Ketetapanyang bersifat rekomendasi; dan (e) Ketetapan yang bersifat perundang-undangan yang berlaku mengikat umum.

Ketetapan-Ketetapan tersebut tidak seluruhnya memenuhi syarat sebagai pératuran perundang-undangan. Ada Ketetapan MPR yang berupa peraturan perundang-undangan dan ada yang berupa keputusan konkrit dan individual. ${ }^{39}$ Untuk meniadakan kerancuan, perlu diadakan pembaharuan mengenai pengertian Ketetapan MPR (mengikat ke luar dan ke dalam) dan Keputusan MPR (mengikat $k e$ dalam) ${ }^{40}$

Sebagai bagian dari sistem peraturan perundang-undangan, Ketetapan MPR semestinya dibatasi pada pengertian aturan tingkah laku yang bersifat abstrak dan mengikat (secara) umum. ${ }^{41}$ Tap. No: III/MPR/2000 memberi pengertian Ketetapan MPR sebagai putusan MPR sebagai pengemban kedaulatan rakyat yang ditetapkan dalam sidang-sidang MPR. ${ }^{42}$ Rumusan yang tidak spesifik inilah yang menyebabkan adanya kerancuan antara Ketetapan MPR yang merupakan peraturan perundang-undangan dan Ketetapan MPR yang bersifat penetapan (beschikking).

Pada era reformasi, paska perubahan $I_{1} I_{\text {, }}$ III, dan IV UUD NegaraRI 1945 terjadi perubahan yang signifikan terhadap kelembagaan MPR. MPR terdiri dari dua kamar (bikameral), yaitu Dewan Perwakilan Rakyatdan Dewan Perwakilan Daerah. Wewenang MPR selanjutnya bersumber pada Pasal 3 ayat (1), (2) dan (3) serta Pasal 8 ayat (2) dan (3) UUD 1945.

Di samping itu, melalui Perubahan Keempat UUD 1945 secara implisit menghendaki peniadaan jenis produk hukum berupa

${ }^{37}$ Mohammad Fajrul'Falaakh et., al., op.cit., him. 18.

38 Jimly Asshiddiqie et., al., Laporan Penelitian Tinjauan Materi dan status Hukum Ketetapan Majelis Permusyawaratan Rakyat (MPRS) dan Majelis Permusyawaratan Rakyat (MPR) Republik Indonesia Tahun 1960-2002, Kejjasama Setjen MPR-Rl dengan Universitas Indonesia, Jakarta, 2003, hlm. 8.

${ }^{39}$ Ketetapan MPR yang konkrit dan individual contohnya adalah Ketetapan mengenai pengangkatan Presiden dan Wakil Presiden.

40 Tap. No. II//MPR/1983.

${ }^{41}$ Bagir Manan, Teori Politik dan Konstitusi, (Jakarta: Dirjen Pendidikan Tinggi Depdiknas, 2000), hlm. 137.

${ }^{42}$ Pasal 3 ayat (2) Tap. No. III/MPR/2000. 
Ketetapan MPR. ${ }^{43}$ Sebagai pelaksanaan amanat konstitusi, MPR melalui Sidang Umum Tahunan MPR 2003 (1-7 Agustus 2003) telah menetapkan Tap No. 1/MPR/2003 tentang Peninjauan terhadap Materi dan Status Hukum Ketetapan MPRS dan MPR Tahun 1960-2003 dengan menggolongkan Tap. MPR/S tersebut ke dalam enam kelompok:

1. Tap. MPR/S yang dicabut dan dinyatakan tidak berlaku, misalnya Tap No. IIIMPRI 1978 tentang Kedudukan dan Hubungan Tata Kerja Lembaga Tertinggi Negara dengan/atau antar Lembaga-lembaga Tinggi Negara.

2. Tap. MPR/S yang dinyatakan tetap berlaku dengan beberapa ketentuan, contoh: Tap No. XXVMPRS/1966 tentang Pembubaran Partai Komunis Indonesia, Pernyataan sebagai Organisasi terlarang di Seluruh Wilayah Negara Republik Indonesia dan Larangan Setiap Kegiatan Untuk Menyebarkan atau Mengembangkan Faham atau Ajaran Komunis/Marxisme-Leninisme, dinyatakan tetap berlaku. Dengan ketentuan seluruh ketentuan dalam Ketetapan MPRS itu kedepan dịberlakukan dengan berkeadilan dan menghormati hukum, prinsip demokrasi, dan HAM.

3. Tap. MPR/S yang tetap berlaku sampai dengan terbentuknya pemerintahan hasil Pemilu 2004, antara lain Tap. No. IVIMPR 1999 tentang GBHN 1999-2004

4. Tap MPR/S yang tetap berlaku sampai dengan terbentuknya UU, antara lain Tap. No. III/MPR/2000 tentang Sumber Hukum dan Tata Urutan Peraturan Perundangundangan.

5. Tap. MPR/S tentang Peraturan Tata Tertib MPR dinyatakan masih berlaku sampai ditetapkannya Peraturan Tata Tertib yang baru oleh MPR hasil Pemilu 2004. Antara lain Tap No. V/MPR/2002 tentang Perubahan Keempat atas Ketetapan MPR No. II.MPR/1999 tentang Peraturan Tata Tertib MPR.

6. Tap. MPR/S yang tidak perlu dilakukan tindakan hukum lebih lanjut, seperti Tap No. XXXIII/MPRS/1967 tentang Pencabutan Kekuasaan Pemerintahan Negara dari Presiden Soekarno.

Berdasarkan Tap. No. I/MPR/2003, penulis berpendapat bahwa Paska Pemilu 2004 MPR tidak diperkenankan untuk membuat Tap yang bersifat sebagai peraturan perundang-undangan. Dengan demikian Tap. MPR harus dikeluarkan dari hirarki peraturan perundang-undangan. Adapun dalam kerangka pelaksanaan tugas dan wewenang MPR sebagaimana diperintahkan konstitusi, penulis berpendapat, bahwa Ketetapan MPR tetap diperlukan, tetapi dengan catatan harus dikembalikan kepada fungsi awal, yaitu sebagai keputusan administratif. ${ }^{44}$

\section{Keputusan Presiden yang Bersifat "Mandiri"}

Dalam penelitan yang dilakukan oleh $A$. Hamid S. Attamimi, dalam kurun waktu Pelita I-Pelita IV terdapat banyak Keputusan Presiden

"Lhat Pasal! Aturan Tambahan UUD Negara RI 1945. Di sampingitu, kewenangan MPRuntuk menetapkan garis-garis besar daripada haluan negara, sebagaimana disebut dalam Pasal 3 UUD 1945 dihapuskan. Kewenangan inilah yang oleh beberapa kalangan dijadikan sebagai salah satu dasar legalitas Ketetapan MPR.

${ }^{44}$ Sebagai bentuk hukum untuk pengangkatan dan pemberhentian Presiden dan/atau Wakil Presiden. 
yang berisi materi pengaturan yang bersifat mandiri, ${ }_{4}{ }^{5}$ dalam arti tidak dimaksudkan untuk melaksanakan ketentuan Undang-Undang atau Peraturan Pemerintah. Praktik tersebut mungkin dapat dibenarkan dengan alasan bahwa Presiden pada saat itu memang memegang kekuasaan membentuk UndangUndang. ${ }^{46}$ Dengan demikian, Presiden itu selain sebagai eksekutif juga mempunyai kedudukan sebagai legislatif. ${ }^{47}$

Pengaturan demikian menimbulkan berbagai persoalan: pertama, kekuasaan Presiden menjadi demikian kuat, termasuk menentukan isi suatu Undang-Undang; kedua: ketentuan ini sangat mengendurkan kemauan DPR untuk menggunakan hak inisiatifnya mengajukan Rancangan Undang-Undang; ${ }^{48}$ ketiga: seolah-olah setiap Rancangan Undang-Undang harus disetujui dan DPR harus menyetujui sesuai kehendak pemerintah, khususnya Presiden. ${ }^{49}$

Untuk memulihkan -kedudukan DPR sebagai pemegang kekuasaan legislatif dan dalam rangka check and balances, diadakanlah perubahan terhadap ketentuan Pasal 20 ayat
(1) yang menegaskan DPR sebagai pemegang kekuasaan membentuk UndangUndang. Demikian pula Pasal 5 ayat (1) diubah menjadi Presiden berhak mengajukan. Rancangan Undang-Undang' kepada DPR.

Mengingat bahwa pada Perubahan Pertama UUD 1945 tersebut cabang kekuasaan legislatif (membientuk Undang-Undang) secara tegas dipindahkan dari Presiden kepada $D P R,{ }^{50}$ maka logika yang mungkin dapat dijadikan pertimbangan pembenar terhadap eksistensi Keputusan Presiden yang mengatur secara mandiri tersebut dengan sendirinya tidak dapat diterima lagi. ${ }^{51}$ Pada prinsipnya Presiden bukan lagi pemegang kekuasaan utama dalam pembentukan Undang-Undang. Presiden hanya diberi hak untuk mengajukan Rancangan UndangUndang.

Dengan demikian, tidak dibenarkan lagi adanya peraturan untuk kepentingan pengaturan yang dibuat oleh Presiden atau Pemerintah secara mandiri. Semua peraturan di bawah Undang-Undang hanyalah merupakan pelaksanaan lebih lanjut dari Peraturan Dasar

${ }^{45}$ A. Hamid Attamimi, Peranan Keputusan Presiden ... op.cit., hlm. 368-371.

${ }^{46}$ Jimly Asshiddiqie, Tata Urut ... op.cit., him. 4-5.

${ }^{47}$ Perhatikan Pasal 4 ayat (1) dan Pasal 5 ayat (1) UUD 1945 (sebelum amandemen). Pasal 4 ayat (1) menyebutkan bahwa Presiden Republik Indonesia memegang kekuasaan pemerintahan menurut UndangUndang Dasar. Selanjutnya Pasal 5 ayat (1) menyebutkan, Presiden memegang kekuasaan membentuk UndangUndang dengan persetujuan Dewan Perwakilan Rakyat. Terhadap pasal ini, kemudian Soepomo memberikan penjelasan yang berbunyi: "Kecuali executive power, Presiden bersama-sama dengan DPR menjalankan legislative power dalam negara."

${ }^{43}$ Menurut data yang dihimpun oleh Mas Soebagio, sejak Proklamasi 17 Agustus 1945 sampai akhir 1974, terdapat sekitar 766 Undang-Undang yang disahkan. Dari jumlah tersebut, yang merupakan usul inisiatif DPR hanya 23 buah (3\%) saja. Mas Soebagio, Aneka Masalah Hukum Tata Negara Republik Indonesia, (Bandung: Alumni, 1976), hlm. 82-83.

${ }^{49}$ Bagir Manan, DPR, DPD, dan MPR dalam UUD 1945 Baru (Yogyakarta: FH UII.Press, 2003), hlm. 21.

${ }^{50}$ Pasal 20 ayat (1) jo. Pasal 5 ayat (1) UUD 1945.

51 Jimly Asshiddiqie, Tata Urut ...op. cit., hlm. 8. 
(UUD) dan Undang-Undang.

Satu-satunya peraturan yang berisi pengaturan yang mandiri hanyalah Peraturan Pemerintah Pengganti Undang-Undang, di mana dari segi isinya seharusnya dituangkan dalam bentuk Undang-Undang, namun dari segi proses pembuatannya ataupun karena adanya faktor eksternal berupa keadaan bahaya atau kegentingan yang memaksa, maka oleh Presiden ditetapkan Peraturan Pemerintah Pengganti Undang-Undang (Perpu) yang bersifat mandiri. ${ }^{52}$ Perpu tersebut harus diajukan untuk mendapat persetujuan DPR menjadi UU dalam persidangan DPR yang berikut, dan apabila tidak disetujui harus dicabut kembali oleh Presiden. ${ }^{53}$

\section{Keputusan Presiden yang bersifat "Menetapkan" dan "Mengatur"}

Meski Presiden tidak diperkenankan lagi untuk mengeluarkan Kepres yang bersifat "mandiri", tetapi Presiden masih memiliki kewenangan untuk mengeluarkan peraturan yang bersifat mengatur sebagai delegasi dari Undang-Undang. Peraturan itu dapat berupa Peraturan Pemerintah maupun Keputusan Presiden. Dalam Tap. No. III/MPR/2000 disebutkan bahwa Keputusan Presiden yang bersifat mengatur dibuat oleh Presiden untuk menjalankan fungsi dan tugasnya berupa pengaturan pelaksanaan administrasi negara dan administrasi pemerintahan.

Khusus untuk Kepres yang bersifat mengatur sebagai delegasian dari UndangUndang atau Peraturan Pemerintah, untuk membedakan dengan Kepres yang bersifar penetapan administratif (beschikking), maka hendaklah diberi nama yang berbeda. Di sini penulis mengusulkan, untuk Keputusan Presiden yang bersifat regeling dituangkan dalam bentuk Peraturan Presiden, sedangkan yang bersifat beschikking tetap dalam bentuk Keputusan Presiden..$^{54}$

Keputusan Presiden yang bersifat beschikking tidak termasuk peraturan perundang-undangan, tetapi ia tergolong sebagai Keputusan Tata Usaha Negara. Dengan demikian terhadap keputusan jenis ini dapat diajukan gugatan ke Pengadilan Tata Usaha Negara. Hal ini dimaksudkan agar jenis peraturan perundang-undangan tersebut mudah dikenal dan sekaligus dibedakan, sehingga tidak membingungkan masyarakat. Keputusan Presiden yang bersifat administratif tidak dapat dikategorikan sebagai peraturan perundang-undangan.

Dalam kerangka untuk menertibkan peraturan yang dibuat oleh Presiden terdapat pemikiran untuk melebur Keputusan Presiden (Peraturan Presiden) ke dalam Peraturan Pemerintah. ${ }^{55} \mathrm{Hal}$ ini dimaksudkan untuk

52 Ibid., hlm. 9. Di Negeri Belanda memang hanya dikenal "Koninkelijk Besluil". Tidak ada "Koninkelijk Verordening". Hal ini berkaitan dengan pembatasan wewenang Raja atau Ratu yang tidakmenjalankan tanggung jawab penyelenggaraan pemerintahan. Pihak yang menjalankan pemerintahan adalah kabinet. Meskipun Raja atau Ratu di sini menandatangani AmvB (serupa PP) tetapi pemerintah di sini adalah "kabinet".

${ }^{53}$ Pasal 22 ayat (1), (2), dan (3) UUD 1945.

${ }^{54}$ Bandingkan dengan Bagir Manan, Teori dan Politik ... op.cit., hlm. 141, dan Jimly Asshiddjqie, Tata Urut ...op:cit, hlm. 5.

${ }^{55}$ Abdul Razak dan M. Guntur Hamzah, "Tanggapan atas Laporan Akhir Kajian tentang Peninjauan 
mengurangi kekuasaan Presiden dalam membuat peraturan perundang-undangan. Menurut Bagir Manan, bentuk Peraturan Presiden tetap diperlukan selama Peraturan Pemerintah dibatasi hanya untuk melaksanakan Undang-Undang. Peraturan Presiden dapat dihilangkan kalau fungsi Peraturan Pemerintah diperluas tidak hanya melaksanakan UU, melainkan juga untuk mengatur administrasi negara pada umumnya. ${ }^{56}$ Untuk keperluan ini tentunya diperlukan amandemen terhadap Pasal 5 ayat (2) UUD 1945.

Dalam sistem ketatanegaraan Indonesia, Presiden menjalankan fungsi (bahkan memimpin) penyelenggaraan pemerintahan (adminsitrasi negara). Administrasi negara menjalankan wewenang mengatur (regelen) dan menjalankan pemerintahan (besturen). Presiden sebagai adminsitrasi negara dapat membuat aturan administrasi untuk menjalankan fungsi administrasi negara. ${ }^{57}$

\section{Peraturan/Keputusan Menteri dan Lembaga Pemerintahan Setingkat Menteri}

Dalam praktik ketatanegaraan, setidaknya kita menjumpai tiga jenis produk hukum yang dikeluarkan oleh menteri, yaitu Peraturan
Menteri, Keputusan Menteri, dan Keputusan Bersama Menteri.58 Sistem peraturan perundangundangan Indonesia tidak mengatur secara jelas tentang jenis produk hukum yang dikeluarkan oleh Menteri. ${ }^{59}$ Akibatnya tidak ada kesatuan bentuk produk hukum yang dipergunakan. Ada kementerian yang menggunakan bentuk hukum "Peraturan", tetapi ada yang menggunakan bentuk hukum "Keputusan". Keputusan Bersama Menteri biasanya dipergunakan untuk mengatur hal-hal yang melintasi batas kewenangan lebih dari satu kementerian.

Meski demikian, diakui. bahwa setiap kementerian pasti mengeluarkan peraturan untuk mengatur teknis pelaksanaan kegiatannya dalam lingkup departemen atau tugasnya masing-masing. Untuk itu, maka diperlukan adanya suatu bentuk hukum tertentu yang menjadi wadah bagi kebijakan tiap-tiap menteri. Sebagai pembantu Presiden dalam melaksanakan tugas pemerintahan, maka menteri sayogyanya juga memiliki kewenangan membentuk peraturan sebagaimana Presiden. Peraturan tersebut diperlukan untuk melaksanakan lebih lanjut kebijakan yang telah digariskan oleh Presiden.

Dalam hirarki peraturan perundangundangan yang diatur Tap. No. III/MPR/2000 tidak disebut Keputusan (Peraturan) Menteri.

terhadap Materi dan Status Hukum Ketetapan MPRS dan MPR Tahun 1960-2002", Makalah dalam Diskusi Panel Peninjauan terhadap Materi dan Status Hukum Ketetapan MPRS dan MPR RI Tahun 1960-2002, Kerjasama Setjen MPR-Rl dengan.UGM, di Hotel Plaza Yogyakarta, 26 Mei 2003, hlm. 5.

${ }^{36}$ Bagir Manan, Teori dan Politik ... loc. cit.

57 lbid.

${ }^{58}$ Keputusan Bersama Menteri biasa disebut dengan Surat Keputusan Bersama (SKB).

${ }^{59}$ Pasal 4 ayat (2) Tap. Nomor III/MPR/2000 hanya menyebutkan: "Peraturan atau Keputusan Mahkamah Agung, Badan Pemeriksa Keuangan, Menteri, Bank Indonesia, Badan, Lembaga, atau komisi yang setingkat yang dibentuk oleh pemerintah tidak boleh bertentangan dengan ketentuan yang termuat dalam perundangundangan ini". 
Sepintas lalu berdasar Tap. MPR tersebut, seolah-olah menteri sebagai pejabat administrasi negara tidak berwenang membuat keputusan, baik yang mengatur atau menerapkan. Tetapi, bila dikaji lebih teliti, secara tidak langsung Pasal 4 ayat (3) Tap. No. III/MPR/2000 mengakui keberadaan Peraturan dan Keputusan Menteri.

Dalam kaitan ini, Bagir Manan memberikan catatan:

"Dalam sistem ketatanegaraan di manapun, wewenang menteri membuat peraturan (administratif) diakui dan mempunyai sifat peraturan perundangundangan. Menteri selain sebagai pejabat publik adalah pejabat administrasi negara. Sebagai pejabat administrasi negara, menteri -untuk melaksanakan hak dan kewajiban atau wewenang departemennya. berhak membuat aturan-aturan. Wewenang mengatur ini dapat bersumber dari atribusi, delegasi, mandat, atau dasar kebebasan bertindak (freiesermessen, discretion, discretionary powers). Berdasarkan aneka ragam sumber wewenang mengatur tersebut, maka pengertian mengatur tidak hanya terbatas pada peraturan perundangundangan, tetapi juga termasuk Peraturan Kebijakan (beleidsregel), dan berbagai bentuk keputusan yang bersifat umum lainnya. Kumpulan dari aneka ragam ini di Belanda dinamakan "besluiten van algemene strekking.60

Berdasarkan uraian di atas, penulis mengusulkan dua bentuk keputusan yang dikeluarkan oleh menteri: (1) Peraturan Menteri; dipergunakan untuk memberi bentuk hukum kebijakan menteri yang bersifat pengaturan (regeling), sebagai tindak lanjut dari pelaksanaan Peraturan Pemerintah dan Peraturan Presiden; (2) Keputusan Menteri; dipergunakan untuk kebijakan menteri yang bersifat penetapan administratif (beschikking). Jenis Keputusan Menteri yang pertama dapat digolongkan ke dalam peraturan perundangundangan, sedangkan keputusan yang kedua termasuk ke dalam kategori Keputusan Tata Usaha Negara. Pembagian jenis keputusan di atas, juga berlaku bagi Lembaga Pemerintahan Setingkat Menteri. Dengan demikian, lembaga inipun juga dapat mengeluarkan keputusan dalam bentuk Peraturan dan Keputusan sebagaimana yang dikeluarkan menteri.

Untuk Keputusan Bersama Menteri, sebaiknya tidak dipergunakan lagi. Apabila ingin mengatur hal-hal yang melintasi batas kewenangan beberapa menteri, maka produk hukumnya dapat diwujudkan dalam bentuk Peraturan Presiden (Keputusan Presiden), ${ }^{61}$ dengan alasan bahwa Presiden adalah kepala pemerintahan yang membawahi para menteri.

\section{Wewenang Lembaga Negara Lain Membentuk Peraturan}

Di dalam Pasal 4 ayat (2) Tap. No. II//MPRI 2000 dijelaskan, Peraturan atau Keputusan Mahkamah Agung, Badan Pemeriksa Keuangan, Bank Indonesia, badan, lembaga

${ }^{60}$ Bagir Manan, "Tertib Peraturan Perundang-undangan Menurut Ketetapan MPR RI Nomor Ill/MPR 2000," Material Course Hukum Perundang-undangan, Jakarta, 2000, hlm. 12.

${ }^{\text {"D }}$ Diberi bentuk hukum Peraturan Presiden apabila bersifat peraturan perundang-undangan atau Keputusan Presiden apabila merupakan keputusan yang bersifat penetapan (beschikking). 
atau komisi yang setingkat yang dibentuk oleh pemerintah tidak boleh bertentangan dengan ketentuan yang termuat dalam tata urutan peraturan perundang-undangan ini.

Ketentuan di atas menimbulkan pertanyaan: (1) apakah Peraturan dan Keputusan lembaga-lembaga di atas termasuk ke dalam kategori peraturan perundangundangan? Apakah yang dimaksud dengan badan, lembaga atau komisi yang setingkat yang dibentuk oleh pemerintah? Terhadap pertanyaan di atas, khusus terkait dengan Peraturan dan Keputusan Menteri telah dibahas pada penjelasan sebelumnya.

Adapun status produk hukum yang dikeluarkan oleh lembaga negara lain selain Presiden dan Menteri dapat dijelaskan di sebagai berikut:

\section{a. Majelis Permusyawaratan Rakyat}

MPR berwenang untuk mengubah dan menetapkan UUD sebagai pelaksanaan tugas konstitusionalnya, ${ }^{62}$ Dengan demikian MPR dapat membentuk peraturan perundangundangan, yaitu dalam bentuk hukum "UUD dan Perubahan UUD." Di samping itu, sebagaimana dijelaskan di depan, MPR juga dapat mengeluarkan Ketetapan atau peraturan MPR, sebagai pelaksanaan dari tugas konstitusionalnya yang lain. ${ }^{63}$ b. Dewan Perwakilan Rakyat dan Dewan Perwakilan Daerah

DPR sebagai lembaga legislatif memiliki kekuasaan untuk membentuk peraturan perundang-undangan dalam bentuk UndangUndang bersama-sama dengan Presiden. Undang-Undang adalah aturan tingkah laku yang dibentuk oleh DPR dan disahkan oleh Presiden. Rumusan demikian sebagai konsekuensi dari Perubahan Pertama UUD 1945 yang mengubah wewenang membentuk UU dari Presiden ke DPR. Perubahan wewenang membentuk UU itu semestinya membawa konsekuensi perubahan format Undang-Undang, di mana frase "Presiden Republik Indonesia"64 yang mengawali setiap Undang-Undang hendaknya diganti dengan "Dewan Perwakilan Rakyat Republik Indonesia". UU ini memiliki cakupan yang luas, karena pada dasarnya segala sesuatu dapat diatur dengan UU, kecuali terhadap hal yang telah ditetapkan diatur dengan peraturan lain. ${ }^{65}$

Dalam hal materi yang akan menjadi muatan suatu RUU berkaitan dengan otonomi daerah, hubungan pusat dan daerah; pembentukan, pemekaran, dan penggabungan daerah; pengelolaan sumber daya alam dan sumber daya ekonomi lainnya, serta perimbangan keuangan pusat dan daerah, Dewan Perwakilan Daerah (DPD) turut serta dalam pembahasan RUU tersebut. ${ }^{66}$

${ }^{62}$ Pasal 3 ayat (1) jo. Pasal 37 ayat (1), (2), (3), (4), dan (5) UUD 1945.

${ }^{63}$ Pasal 3 ayat (2) dan (3) serta Pasal 8 ayat (1), (2), dan (3) UUD 1945. Ketetapan MPR tersebut merpakan keputusan adm nistatif beschikking), sedangkan Peraturan MPR merupakan peraturan yang sifatnya interne regelingen. Keduanya tidak tergolong peraturan perundang-undangan.

${ }^{64}$ Frase ini menunjukkan Presiden yang membentuk Undang-Undang dengan persetujuan Dewan Perwakilan Rakyat.

${ }^{65}$ Bagir Manan, Teori dan Politik ... op.cit, hlm. 138.

${ }^{66}$ Pasal 22 D Ayat (2) UUD 1945. 
Seperti hainya MPR, DPR dan DPD. juga memiliki kewenangan. untuk membuat peraturan yang sifatnya interne regelingen. Peraturan demikian tidak termasuk ke dalam jenis peraturan perundang-undangan.

\section{c. Mahkamah Agung dan Mahkamah} Konstitusi

MA dan MK merupakan lembaga negara yang melaksanakan kekuasaan kehakiman. MK adalah lembaga baru yang dibentuk setelah Perubahan Ketiga UUD $1945 .{ }^{67}$ MA oleh Undang-Undang diberi wewenang menetapkan Peraturan Mahkamah Agung (Perma). ${ }^{68}$ Perma adalah semacam aturan kebijakan yang ditujukan kepada aparaturnya sendiri dan diadakan untuk melancarkan pekerjaan peradilan. Sebagai aturan yang menyerupai aturan kebijakan, Perma tidak berada dalam tata urutan peraturan perundangundangan, karena itu tidak diuji terhadap peraturan perundang-undangan, melainkan dengan asas-asas umum peraturan perundangundangan dan pemerintahan yang baik, seperti asas melampaui wewenang, asas kewenangan, dan lain-lain. ${ }^{69}$

Di samping Perma, dalam praktik MA juga membuat pengaturan yang diwujudkan dalam bentuk Surat Edaran Mahkamah Agung (SEMA). Istilah SEMA ini tidak dijumpai di dalam sistem peraturan perundang-undangan, ${ }^{70}$ tetapi ia tumbuh dan berkembang di dalam praktik. SEMA bukanlah peraturan perundangundangan; ia lebih merupakan peraturan yang sifatnya interne regelingen atau sebagaj bentuk hukum dari kewenangan diskresi yang dimiliki oleh Mahkamah Agung. R. Soebekti pernah menegaskan bahwa SEMA bukanlah sumber hukum, karena itu ia tidak mengikat. Kedudukan SEMA hanya anjuran ạtau saran kepada para pengadilan, bukan kepada para hakim. ${ }^{71}$.

\section{d. Badan Pemeriksa Keuangan}

Sebagaimana DPR dan MA, BPK sebagai suatu lembaga yang kedudukan dan wewenangnya diatur di dalam UUD, ${ }^{72}$ juga memiliki kewenangan untuk membuat pengaturan yang bersifat interne regelingen atau merupakan Peraturan Kebijakan (beleidsregel, policy rule). Kewenangan membuat ketentuan tersebut merupakan kewenangan yang dimiliki oleh setiap lembaga.

e. Bank Indonesia

BI adalah badan negara (dalam UU disebut lembaga negara) yang independen yang berfungsi sebagai bank sentral. BI berwenang mengeluarkan Peraturan Bank Indonesia yang materi muatannya mempunyai sifat sebagai peraturan perundang-undangan ${ }^{73}$

Menurut Bagir Manan, meskipun BI adalah "independent agency", bahkan disebut lembaga negara, tetapi fungsi BI dilihat dari fungsi-fungsi negara secara hakiki masuk

\footnotetext{
${ }^{67}$ Keberadaan MK dikukuhkan dengan disahkannya UU No. 25 Tahun 2003 tentang Mahkamah Konstitusi.

${ }^{66}$ Pasal 79 UU No. 14 Tahun 1985 tentang Mahkamah Agung.

${ }^{69}$ Bagir Manan, Teori dan Politik ...op. cit., him. 148.

70 Jimly Asshiddiqie, Tata Urut ...op. cit., hlm. 1.

"Budiman S. Sagala, Tugas dan Wewenang MPR di Indonesia (Jakarta: Ghalia Indonesia, 1982), hlm. 243.

${ }^{72}$ Pasal 23 E, Pasal 23 F, dan Pasal 23 G UUD 1945.

73 UU Nomor 23 Tahun 1999 tentang:Bank Indonesia.
} 
dalam fungsi pemerintahan atau administrasi negara. Karena itu, Peraturan BI pada dasarnya adalah peraturan administrasi negara. Untuk menguji Peraturan BI tidak menggunakan prinsip tata urutan peraturan perundang-undangan, melainkan pada ukuran wewenang. Sepanjang peraturan tersebut dalam wewenang $\mathrm{Bl}$, maka semua peraturan administrasi lain mesti dikalahkan. Demikian juga sebaliknya, kalau Peraturan BI melanggar batas wewenang dan bertentangan dengan peraturan administrasi lainnya (mulai dari PP dan seterusnya) harus dibatalkan. ${ }^{74}$

Di samping dalam bentuk Peraturan, BI juga menggunakan bentuk hukum lain dalam memberikan aturan terhadap dunia perbankan, yaitu Surat Edaran Bank Indonesia (SEBI). Menurut pandangan penulis, baik Peraturan $\mathrm{BI}$ maupun SEBI, masing-masing merupakan peraturan yang bersifat internal. Artinya khusus mengatur dunia perbankan. Dengan demikian, kedua jenis aturan tersebut tidak dapat dikategorikan sebagai peraturan perundangundangan, tetapi lebih merupakan interne regelingen atau beleidsregel.

Berdasar ulasan di atas, penulis menilai bahwa ketentuan Paśal 4 ayat (2) Tap. Nomor III/MPR/2000 yang menyebut adanya jenis hukum peraturan dan keputusan pada beberapa lembaga negara (Menteri, MA, BPK, Menteri, $\mathrm{Bl}$, badan, lembaga atau 'komisi yang setingkat yang dibentuk oleh pemerintah) mengandung beberapa kelemahan. Di sini dapat dipertanyakan, apakah jenis peraturan dan keputusan lembaga-lembaga tersebut termasuk ke dalam kategori peraturan perundang-undangan? Dan apakah yang dimaksud dengan badan, lembaga, atau komisi yang setingkat yang dibentuk oleh pemerintah?

Menurut penulis, berdasarkan pada kajian di atas, jenis peraturan yang termasuk ke dalam peraturan perundang-undangan adalah Peraturan Menteri dan Peraturan Lembaga Pemerintahan Setingkat Menteri. ${ }^{75}$ Sedangkan peraturan atau keputusan lembaga negara lain (termasuk di dalamnya Keputusan Menteri dan Keputusan Lembaga Pemerintahan Setingkat Menteri) bukan termasuk ke dalam hirarki peraturan perundang-undangan. Peraturan dan Keputusan jenis terakhir ini lebih dekat kepada peraturan yang bersifat interne regelingen atau sebagai Peraturan Kebijakan (beleidsregel).

\section{Peraturan Gubernur, BupatiWalikota, dan Kepala Desa}

Di dalam Tap. No. III/MPR/2000 dijelaskan bahwa. Peraturan Daerah adalah peraturan untuk melaksanakan aturan hukum di atasnya dan menampung kondisi khusus dari daerah yang bersangkutan. Peraturan Daerah ini terdiri dari:

a. Peraturan Daerah Provinsi, dibuat oleh Dewan Perwakilan Rakyat Daerah Provinsi bersama dengan Gubernur;

b. Peraturañ Daerah Kabupaten/Kota, dibuat

${ }^{74}$ Bagir Manan, Teori dan Politik ...op.cit., hlm. 148-149.

${ }^{75}$ Dalam pemahaman penulis, pengertian "badan, lembaga atau komisi setingkat yang dibentuk pemerintah" adalahlembaga pemerintahan yang setingkat dengan menteri, yang biasa disebut dengan Lembaga Pemerintahan Non Departemen (LPND). Bandingkan dengan Jimly Asshiddjiqiè, Tata Urut ...op.cit., hlm. 12. 
oleh Dewan Perwakilan Rakyat Daerah Kabupaten/Kotabersama BupatiWalikota; dan.

c. Peraturan Desa atau yang setingkat, dibuat oleh Badan Perwakilan Desa atau yang setingkat.

Perda merupakan jenis peraturan perundang-undangan yang disebut paling akhir di dalam Tap. No. III/MPR/2000. Hal ini tidak berarti bahwa di bawah itu tidak terdapat peraturan perundang-undangan lainnya. ${ }^{76}$ Untuk melaksanakan Perda, Kepala Pemerintahan yang bersangkutan juga diberi wewenang untuk membuat peraturan yang bersifat pelaksanaan. Oleh karena itu, bila Presiden berwenang mengeluarkan Peraturan Pemerintah dan Peraturan Presiden, maka Gubernur, Bupati/Walikota, dan Kepala Desa juga berwenang mengeluarkan Peraturan Gubernur; Peraturan Bupati/Walikota, dan Peraturan Kepala Desa sebagai pelaksanaan terhadap peraturan yang lebih tinggi tersebut. ${ }^{n}$

Dengan demikian, Gubernur, Bupati/ Walikota, dan Kepala Desa dapat mengeluarkan dua jenis keputusan tertulis, yaitu dalam bentuk:

a. Peraturan; jenis inilah yang merupakan bagian dari hirarki peraturan perundangundangan, sehingga dapat diuji berdasarkan sistem peraturan perundang-undangan. Peraturan Kepala Daerah ini dimaksudkan untuk melaksanakan Peraturan Daerah sesuai dengan tingkatannya masingmasing. b. Keputusan; jenis ini merupakan bentuk dari keputusan administrasi, atau yang biasa disebut sebagai Keputusan Tata Usaha Negara.

\section{Hirarki Peraturan Perundang-Undangan Indonesia}

Di samping dalam hal jenis peraturan perundang-undangan, sistem perundangundangan Indonesia juga menyisakan persoalan-persoalan lain, yaitu terkait dengan tata urutan (hirarki) peraturan perundangundangan. Tata urutan (hirarki) peraturan perundang-undangan ini penting karena berpengaruh terhadap derajat kekuatan masing-masing peraturan perundangundangan. Pasal 4 Tap. No. IIl/MPR/2000 menyebutkan:

"Sesuai dengan tata urutan perundangundangan ini, maka setiap aturan hukum yang lebih rendah tidak boleh bertentangan dengan aturan hukum yang lebih tinggi".

Pengaturan di atas sesuai dengan asas peraturan perundang-undangan yang mengatakan: "lex superiore deregat lex infiriore" (hukum yang lebih tinggi mengalahkan hukum yang tingkatannya di bawahnya). Hal ini dimaksudkan agar tercipta kepastian hukum dalam sistem peraturan perundang-undangan. Ajaran tentang tata urutan (hirarki) peraturan perundang-undangan demikian mengandung beberapa prinsip: ${ }^{78}$

${ }^{78}$ Menurut 'ketentuan Pasal 69 dan 72 ayat (1) UU Nomor 22 Tahun 1999 tentang Pemerintahan Daerah, produk hukum daerah terdiri dari dua macam, Pertama, Peraturan Daerah yang ditetapkan bersama oleh Kepala Daerah dan Dewan Perwakilan Rakyat Daerah (DPRD); Kedua, Keputusan Kepala Daerah yang dikeluarkan oleh Kepala Daerah.

${ }^{77}$ Jimly Asshiddiqie, Tata Urut ...op.cit., him. 8.

${ }^{79}$ Bagir Manan, Teori dan Politik ... op.cit., hlm. 133. Bandingkan dengan Hans Kelsen, Trans. Anders Wedberg, General Theory of law and State (New York: Russel and Russel, 1973), hlm. 133. 
1. Peraturan perundang-undangan tingkat lebih rendah harus bersumber atau memiliki dasar hukum dari suatu peraturan perundang-undangan tingkat lebih tinggi.

2. Isi atau muatan peraturan perundangundangan yang lebih rendah tidak boleh menyimpangi atau bertentangan dengan peraturan perundang-undangan yang lebih tinggi tingkatannya.

Bila dikaji secara mendalam, hirarki peraturan perundang-undangan, sebagaimana diatur Tap. No. IIIMPR/2000, masih menyisakan beberapa masalah mendasar. Beberapa masalah tersebut akan diuraikan di bawah ini:

\section{Kedudukan Peraturan Pemerintah \\ Penganti Undang-Undang (Perpu)}

Menurut Tap. MPR No. III/MPR/2000, dalam hirarki peraturan perundang-undangan Indonesia, Peraturan Pemerintah Pengganti Undang-Undang (Perpu) diletakkan pada nomor urut keempat di bawah UndangUndang. Hal ini dapat menimbulkan penafsiran seakan-akan kedudukan Perpu itu di bawah UU.

Aturan tersebut, baik secarayuridis, teoritis, maupun praktis tidak dapat diterima. Menurut Yusril, secara yuridis penempatan Perpu di bawah. UU bertentangan dengan ketentuan Pasal 22 UUD 1945 beserta Penjelasannya, bahwa Perpu mempunyai kedudukan yang sama dengan UU. Ini berarti Perpu tidak bisa diletakkan pada posisi satu tingkat di bawah
UU. Selain itu, UU juga mustahil dapat dijadikan sebagai pedoman dalam penyusunan setiap Perpu, karena dalam praktik, sangat mungkin pemerintah terpaksa menetapkan Perpu untuk mengubah UU yang telah ada sebelumnya. ${ }^{79}$

Secara teoritis aturan ini juga kurang tepat, karena hakikatnya muatan Perpu sama dengan UU dan memiliki kedudukan yang sejajar. Bila tidak sejajar, bagaimana mungkin Perpu bisa mencabut UU? Perpu dapat mencabut UU karena kedudukan Perpu setingkat dengan UU. Perpu posisinya menggantikan UU dalam kondisi kegentingan yang memaksa. ${ }^{80}$

Demikian juga, dalam praktik Tap. MPR No. III/MPR/2000 di atas tidak berlaku. Hal ini terbukti dengan banyaknya Perpu yang mencabut atau menggantikan UU. Sebagai contoh, Perpu No. 2 Tahun 2000 tentang Kawasan Perdagangan Bebas dan Pelabuhan Bebas Sabang mencabut UU sebelumnya yang mengatur bahwa Sabang sebagai pelabuhan tertutup. ${ }^{81}$

Mengapa Perpu harus berkedudukan sederajat dengan UU? Pertama, materi muatan yang diatur Perpu semestinya diatur dengan UU: Kedua, Perpu adalah cara darurat untuk membentuk, mengubah, mengganti atau mengesampingkan suatu UU. Untuk mencegah penyalahgunaan yang dapat menimbulkan kekacauan hukum, ditentukan syarat formal dan materiel yang kuat. ${ }^{82}$ Syarat formal adalah "sifat kesementaraan." Sebagai "UU" yang dikeluarkan Presiden pada saat

79 Yusril Ihza Mahendra, "Problematika Sekitar Perpu", harian Republika, 8-9 September 2000.

${ }^{\circ}$ Pasal 22 ayat(1) UUD 1945 menegaskan: "Dalam hal ihwal yang memaksa, Presiden berhak menetapkan Peraturan Pemerintah sebagai Pengganti Undang-Undang".

81 Materi Kuliah I Kapita Selekta Hukum Tata Negara, pada Program Maguster Ilmu Hukum UII, sebagaimana disampaikan oleh Moh. Mahfud MD., pada tanggal 18 Oktober 2002.

${ }^{82}$ Bagir Manan, Tertib Peraturan ...op.cit, hlm. 11. 
"genting", maka Perpu itu harus mendapatkan persetujuan dari DPR dalam persidangan berikutnya. ${ }^{83}$ Apabila tidak mendapatkan persetujuan, maka Perpu itu harus dicabut. ${ }^{84}$

Syarat material -ini yang pokok dan konstitutif- adalah harus dapat menunjukkan secara nyata "kegentingan yang memaksa" ${ }^{\mathrm{BS}}$ sebagai dasar materiel lahirnya wewenang membuat Perpu. Tanpa thal inwal kegentingan yang memaksa" Presiden tidak berwenang menetapkan Perpu. ${ }^{86}$

\section{Kedudukan Ketetapan MPR}

Mengingat bahwa paska Pemilu 2004 dimungkinkan tidak akan dijumpai lagi Ketetapan MPR dalam sistem peraturan perundang-undangan Indonesia, maka kedudukan hirarki Ketetapan MPR yang diletakkan di bawah UUD dan Perubahan UUD dengan sendirinya akan hilang dari hirarki peraturan perundang-undangan. Produk hukum MPR yang bersifat sebagai peraturan perundang-undangan hanyalah UndangUndang Dasar dan Perubahan UndangUndang Dasar.

3. Kedudukan Peraturan dan Keputusan MA, $B P K, B I$, Menteri, dan Lembaga lain yang Setingkat yang Dibentuk oleh Pemerintah

Pasal 4 ayat (2) TAP Nomor III/MPR/2000 menyebutkan:

"Peraturan atau Keputusan Mahkamah Agung, Badan Pemeriksa Keuangan, Menteri, Bank Indonesia, Badan, Lembaga, atau Komisi yang setingkat yang dibentuk oleh pemerintah tidak boleh bertentangan . dengan ketentuan yang termuat dalam perundang-undangan ini."

Ketentuan di atas menegaskan bahwa Peraturan dan Keputusan MA, BPK, Menteri, (Gubernur?) BI, serta Peraturan dan Keputusan Badan, Lembaga ataupun Komisi yang setingkat (Menteri?) tidak boleh bertentangan dengan peraturan perundang-undangan (UUD

${ }^{83}$ Pasal 22 ayat (2) UUD 1945.

${ }^{84}$ Pasal 22 ayat (3) UUD 1945. Ketentuan UUD tersebut dipertegas lagi dalam Pasal 3 ayat (4) Tap. Nomor 1:I/MPR2000: "Peraturan Pemerintah Pengganti Undang-Undang dibuat oleh pemerintah dalam hal ihwal kegentingan yang memaksa, dengan ketentuan sebagai berikut: (a) Perpuharus diajukan ke DPR dalam masa persidangan yang berikut; (b) DPR dapat menerima atau menolak Perpu dengan tidak mengadakan penbahan; (c) jika ditolak DPR, Perpu tersebut harus dicabut." Mengenai siapa yang akan mencabut Perpu yang ditolak oleh DPR, menjad, masalah yang cukup problematik. Lihat Yusril Ihza Mahendra, loc. cit.

${ }^{85}$ Menurut Bagir Manan, kegentingan yang memaksa harus menunjukkan: (1) ada krisis yang menimbulkan bahaya atau hambatan secara nyata terhadap kelancaran menjalankan fungsi pemerintahan. Hambatan ini bersumber pada peratutan perundang-undangan yang ada atau karena suatu kekosongan yang bersifat sangat mendesak dan harus dipecahkan dengan sangat segera. Krisis itu memerlukan pengaturan segera pada tingkatan Undang-Undang. (2) Materi muatan Perpu hanya terbatas pada pelaksanaan fungsi pemerintahan (administrasi negara). Perpu tidak dapatmencakup bidang ketatanegaraan (staatsrechtelijk).

Hal-hal yang berkaitan dengan kelembagaan negara, seperti soal-soal peradilan tidak boleh diatur dengan Perpu. (3) Perpu hanya dapat ditetapkan pada saat DPR sedang tidak bersidang (reses). Apabila DPR dalam masa bersidang, Presiden dilarang menetapkan perpu. Bagir Manan, Teori dan Politik ...op.cit., hlm. 139-140.

${ }^{86}$ Suatu Perpu yang ditetapkan tanpa secara nyata menunjukkan "kegentingan yang memaksa" adalah batal demi hukum karena dibuat tanpa wewenang (onbevoegd). 
sampai dengan Perda). Pengaturan demikian menurut Jimly Asshiddiqie menimbulkan beberapa masalah, antara lain: ${ }^{87}$

a. Apakah Peraturan dan Keputusan yang ditetapkan oleh lembaga tinggi negara seperti MA dan BPK dianggap sederajat dengan Peraturan dan Keputusan yang dikeluarkan oieh Menteri, Bl, dan bahkan badan, Lembaga, atau Komisi sederajatyang dibentuk oleh Pemerintah?

b. Apakah Peraturan Mahkamah Agung dan Peraturan Badan Pemeriksa Keuangan tidak boleh bertentangan dengan Peraturan Pemerintah, tidak boleh bertentangan dengan Keputusan Presiden, dan bahkan tidak boleh bertentangan dengan Peraturan Daerah Propinsi, Peraturan Daerah Kabupaten/Kota, dan Peraturan Desa?

c. Apakah Keputusan Mahkamah Agung dalam menyelesaikan sesuatu perkara kasasi tidak boleh bertentangan dengan semua ketentuan perundangundangan yang tingkatannya di bawah Undang-Undang? Padahal sesuai dengan asas kebebasan hakim, demi keadilan berdasarkan Ketuhanan Yang Maha Esa, putusan hakim dapat saja bertentangan dengan Undang-Undang.

d. Apakah kedudukan Perda lebih tinggi daripada Peraturan atau Keputusan
Menteri, sehingga pembuatan dan penetapan Perda di daerah-daerah tidak perlu mengacu kepada pedoman yang ditetapkan oleh Menteri.

Masalah-masalah di atas, dapat diselesaikan tentunya dengan memperbaiki Tap. Nomor IIIMPR/2000. Dalam hal ini kedudukan masing-masing lembaga harus diperjelas, termasuk juga status peraturan yang dikeluarkannya. Menurut penulis, sebagaimana dijelaskan pada sub bab sebelumnya, dari beberapa lembaga tersebut, yang berwenang untuk mengeluarkan keputusan tertulis yang bersifat peraturan perundangundangan hanyalah Menteri dan Lembaga Pemerintahan Non Departemen. Keputusan tertulis tersebut dalam bentuk "peraturan". ${ }^{88}$

Peraturan Menteri dan Peraturan Lembaga Pemerintahan Non Depertemen, mengingat bahwa lembaga-tembaga tersebut dibentuk oleh Presiden, maka peraturanperaturan yang dibentuk oleh lembagalembaga tersebut kedudukannya jelas berada di bawah produk hukum yang dikeluarkan Presiden. Peraturan perundang-undangan yang dibuat oleh lembaga-lembaga tersebut merupakan pelaksanaan lebih lanjut dari Peraturan Presiden. Oleh karena itu, peraturanperaturan tersebut harus mendapatkan atribusi dari Peraturan Pemerintah danlatau Peraturan Presiden.

4. Peraturan Daerah dan Peraturan Menteri ${ }^{29}$ Sebelum adanya Tap. No. III/MPR/2000,

${ }^{87}$ Jimly Asshiddiqie, Tata Urut ...op. cit., hlm. 12.

${ }^{83}$ Keputusan tertulis yang bersifat pengaturan yang dikeluarkan oleh MA, MK, BPK, dan BI pada dasamya merupakan pengaturan yang sifatnya interne regelingen (ditujukan untuk intem lembaga yang bersangkutan) atau berupa Peraturan Kebijakan (beleidsregel, policy rule).

${ }^{89}$ Peraturan Menteri yang dimaksudkan di sini adalah keputusan tertulis yang dikeluarkan oleh Menteri yang bersifat sebagai peraturan perundang-undangan. 
Peraturan Menteri merupakan instrumen penting dalam penyelenggaraan pemerintahan. Setiap Perda hampir semuanya mendasarkan pada Peraturan Menteri. Hal ini dikarenakan Peraturan Menteri masuk ke dalam hirarki peraturan perundang-undangan, dan kedudukannya di bawah Keputusan Presiden. Setelah adanya Tap. No. III/MPR/2000 terjadi perdebatan di seputar kedudukan Peraturan (Keputusan) Menteri, apakah termasuk peraturan perundang-undangan atau tidak, dan bagaimanakah kedudukannya dalam tata urutan perundang-undangan.

Pertanyaan di atas muncul karena dalam tata urutan perundang-undangan yang diatur Tap. di atas Peraturan Menteri tidak dimasukkan. Padahal dalam praktik ketatanegaraan, keberadaan peraturan tersebut sangat penting dalam penyelenggaraan pemerintahan di daerah. Hal ini didukung oleh kenyataan bahwa Peraturan Pemerintah yang diamanatkan oleh UU untuk dibentuk belum semuanya dibuat, sehingga terjadi kekosongan hukum. Di sini Peraturan Menteri berperan penting dalam mengisi kekosongan tersebut. Untuk itu, maka penulis mengusulkan agar Peraturan Menteri dimasukkan ke dalam struktur tata urutan perundang-undangan dan kedudukannya berada di bawah Peraturan Presiden. Dengan demikian, kedudukan Peraturan Daerah berada di bawah Peraturan Menteri.

Meski demikian, mengingat bahwa Peraturan Daerah (termasuk Peraturan Desa) dibuat oleh satuan pemerintahan yang mandiri (otonom), dengan lingkungan wewenang yang mandiri pula, maka dalam pengujiannya terhadap peraturan perundang-undangan yang lebih tinggi tidak boleh semata-mata berdasarkan "pertingkatan", melainkan juga pada "lingkungan wewenangnya". Suatu Peraturan Daerah yang bertentangan dengan suatu peraturan perundang-undangan tingkat lebih tinggi (kecuali UUD) belum tentu salah, kalau ternyata peraturan perundang-undangan tingkat tinggi yang melanggar hak dan wewenang daerah yang dijamin UUD atau Undang-Undang Pemerintahan Daerah. ${ }^{90}$

Dalam perspektif yang berbeda, Fajrul Falaakh menilai bahwa penempatan Perda pada tingkatan yang terendah dalam hirarkiperaturan perundang-undangan masih dijiwai oleh mekanisme hubungan pusatdaerah menurut UU No. 5 Tahun 1974 tentang Pemerintahan Daerah. Menurut UU No. 22 Tahun 1999 tentang Pemerintahan Daerah, daerah dapat mengeluarkan peraturan untuk bidang-bidang yang telah mengalami desentralisasi. Dengan demikian Perda berstatus "menggantikan" UU mengeni bidang desentralisasi, khusus untuk daerah yang bersangkutan. Perda tidak selalu dalam hirarki paling bawah dalam tata urut peraturan perundang-undangan, sehingga harus ditundukkan kepada Peraturan Pemerintah dan/atau Keputusan Presiden.91

Menanggapi pendapat Fajrul Falaakh di atas, penulis sependapat dengan pandangan Bagir Manan bahwa, meski Perda berada pada hirarki terakhir dalam tata urut peraturan perundang-undangan, pengujiannya terhadap peraturan perundang-undangan yang lebih tinggi tidak boleh semata-mata berdasarkan

\footnotetext{
${ }^{90}$ Bagir Manan, Teori dan Politik ...op.cit,, hlm. 142.

"1 Mohammad Fajul Falaakh, et., al., op.cit., hlm. 61.
} 
"pertingkatan", melainkan juga pada "lingkungan wewenangnya". Dengan demikian, bisa jadi ketika terjadi pertentangan antara Perda dengan PP (atau bahkan dengan UU), Perda yang dimenangkan, dengan alasan PP atau UU telah melampaui wewenang yang telah didesentralisasikan kepada daerah otonom.

5. Kedudukan Perda Propinsi, Perda kabupaten/Kota, dan Perdes

Pasal 3 ayat (7) Tap. No. III/MPR/2000 menyebutkan: "Peraturan Daerah merupakan peraturan untuk melaksanakan aturan hukum di atasnya dan menampung kondisi khusus dari daerah yang bersangkutan, terdiri dari Peraturan Daerah Propinsi, Peraturan Daerah Kabupaten/Kota, dan Peraturan Desa".

Pengaturan tersebut memunculkan pertanyaan, bagaimanakah kedudukan Perda Propinsi, Perda Kabupaten/Kota, dan Perdes, apakah masing-masing memiliki kedudukan yang sederajat, ataukah berbeda? Kedudukan masing-masing tersebut penting dalam kaitannya dengan Pasal 4 ayat (1) Tap. Nomor III/MPR/2000, di mana kedudukan terkait erat dengan derajat kekuatan masing-masing peraturan.

UU No. 22 Tahun 1999 tentang Pemerintahan Daerah mengatur bahwa hubungan antara daerah propinsi dan daerah kabupaten/kota tidak lagi bersifat hirarkis, melainkan koordinatif, dan horizontal. Bila mengingat ketentuan demikian, maka masing-masing Perda tersebut memiliki kedudukan yang sederajat.

Namun demikian, penulis menilai bahwa bila peraturan-peraturan tersebut diletakkan pada derajat yang sama, maka akan menimbulkan sengketa peraturan perundang- undangan di mana-mana, antara Perda Propinsi bisa jadi bertentangan dengan Perda Kabupaten/Kota, dan bahkan tidak menutup kemungkinan akan terjadi pertentangan antara Perda Kabupaten/Kota dengan Perda Kabupaten/Kota lainnya.

Untuk itu, penulis mengusulkan, agar masing-masing peraturan tersebut dibuat secara berjenjang. Perda Propinsi menempati posisi tertinggi, diikuti Perda Kabupaten/Kota; baru kemudian Peraturan Desa. Pelaksanaan pengaturan demikian tentunya dengan memperhatikan kewenangan masing-masing Daerah, sebagaimana di atur dalam BAB IV UU No. 22 Tahun 1999 tentang Pemerintahan Daerah dan Peraturan Pemerintah Nomor 25 Tahun 2000 tentang Kewenangan Propinsi sebagai Daerah Otonom.

Di samping itu, dalam pelaksanaan prinsip "lex superiore derogat lex infiriore harus diimbangi dengan prinsip lain, yaitu "lex specialis deregat lex generalis", bahwa norma hukum yang khusus, baik materinya maupun wilayah berlakunya ataupun waktu berlakunya, dapat saja mengatur yang berbeda dari norma hukum yang bersifat umum tersebut..$^{22}$ Dalam penerapan asas ini tentunya terkait erat dengan kewenangan masing-masing daerah sebagaimana di atur oleh peraturan perundangundangan di atas.o

\section{Simpulan}

Uraian di atas menunjukkan, bahwa sistem peraturan perundang-undangan Indonesia setelah amandemen UUD 1945 ternyata masih menyisakan beberapa masalah mendasar terkait dengan jenis dan tata urutannya. Seiring

${ }^{92}$ Jimly Asshiddiqie, Tata Urut ... op.cit., hlm. 13. 
dengan ketentuan Tap. No. I/MPR/2003 tentang Peninjauan terhadap Materi dan Status Hukum Ketetapan MPRS dan MPR Tahun 1960-2003 yang mengelompokkan Tap. No. IIIMPR/2003 sebagai Ketetapan MPR yang masih berlaku sampai dibentuknya UU, maka penulis merekomendasikan kepada lembaga pembentuk UU untuk segera membuat UU yang mengatur tentang Ketentuan-Ketentuan Pokok Peraturan Perundang-undangan guna menertibkan dan menyempurnakan sistem peraturan perundang-undangan Indonesia. UU tersebut setidaknya mengatur tentang jenis-jenis peraturan perundang-undangan beserta pengertiannya masing-masing, tata urutan dan konsekuensi yuridisnya, serta mekanisme menegakkan tata urutan tersebut melalui sistem pengujian terhadap peraturan perundang-undangan.o

\section{Daftar Pustaka}

Asshiddiqie, Jimly, "Tata Urut PerundangUndangan dan Problema Peraturan Daerah", Makalah dalam Lokakarya Anggota DPRD se-Indonesia, diselenggarakan oleh LP3HET, Jakarta, 22 Oktober 2000.

, "Reformasi Menuju Indonesia Baru: Agenda Restrukturisasi Organisasi Negara, Pembaruan Hukum, dan Keberdayaaan Masyarakat", Makalah disampaikan pada Forum Konggres Mahasiswa Indonesia Sedunia I, Chicago, AS, 2001.

Materi dan status Hukum Ketetapan Majelis Permusyawaratan Rakyat (MPRS) dan Majelis Permusyawaratan
Rakyat (MPR) Republik Indonesia Tahun 1960-2002, Kerjasama Setjen MPR-RI dengan Universitas Indonesia, Jakarta, 2003.

Attamimi, A. Hamid S. , Peranan Keputusan Presiden Republik Indonesia dalam Penyelenggaraan Pemerintahan Negara, Jakarta: Fakultas Pasca Sarjana Universitas Indonesia, 1990.

- Teori Perundang-undangan Indonesia, Suatu Sisi IImu Pengetahuan Perundang-undangan Indonesia yang Menjelaskan dan Menjernihkan Pemahaman, Pidato Pengukuhan Jabatan Guru Besar Tetap pada Fakultas Hukum Universitas Indonesia, 25 April 1992.

Falaakh, Mohammad Fajrul, et., al., Laporan Akhir Kajian tentang Peninjauan terhadap Materi dan Status Hukum Ketetapan MPRS dan MPR Tahun 1960-2002, Kerjasama Setjen MPR-RI dengan UGM, Yogyakarta, 2003.

Kelsen, Hans, Trans. Anders Wedberg, General Theory of law and State, New York: Russel and Russel, 1973.

Lubis, M. Solly, Landasan dan Teknik Perundang Undangan, Ctk III, Bandung: Mandar Maju, 1989.

Manan, Bagir, Dasar-Dasar PerundangUndangan Indonesia, Jakarta: Ind-Hill. $\mathrm{Co}_{1}, 1992$.

, Tertib Peraturan Perundang-undangan Menurut Ketetapan MPR RI Nomor III MPR/2000, Material Course Hukum Perundang-undangan, Jakarta, 2000. 
Teori Politik dan Konstitusi, Jakarta: Dirjen Pendidikan Tinggi Depdiknas, 2000.

— DPR, DPD, dan MPR dalam UUD 1945 Baru, Yogyakarta: FH Ull Press, 2003.

Mahendra, Yusril linza, "Problematika Sekitar Perpu", Republika, 8-9 September 2000.

M, R. Sri Soemantri., Prosedur dan Sistem Perubahan Konstitusi, Bandung: Alumni, 1987.

- Ketetapan MPR(S) sebagai Salah Satu Sumber Hukum Tata Negara, Bandung: Remaja Karya, 1988.

—. Hak Uji Material di Indonesia, Edisi Kedua, Bandung: Alumni, 1997.

— UUD 1945, Kedudukan dan AspekAspek Perubahannya, Bandung: Unpad Press, 2002.

Prakoso, Djoko, Proses Pembuatan Peraturan Daerah, Jakarta: Ghalia Indonesia, 1985.

Ranggawidjaja, Rosjidi, Pedoman Teknik Perancangan Peraturan PerundangUndangan, Bandung: Cita Bakti Akademika, 1996.

—. Pengantar Ilmu Perundang-undangan Indonesia, Bandung: Mandar Maju, 1998.

Razak, Abdul, dan M. Guntur Hamzah, "Tanggapan atas Laporan Akhir Kajian tentang Peninjauan terhadap Materi dan Status Hukum Ketetapan MPRS dan MPR Tahun 1960-2002", Makalah dalam Diskusi Panel Peninjauan terhadap Materi dan Status Hukum Ketetapan MPRS dan MPR RI Tahun -1960-2002, Kerjasama Setjen MPR-RI dengan UGM, di Hotel Plaza Yogyakarta, 26 Mei 2003.

Sagala, Budiman S., Tugas dan Wewenang MPR di Indonesia, Jakarta: Ghalia Indonesia, 1982.

Soebagio, Mas, Aneka Masalah Hukum Tata Negara Republik Indonesia, Bandung: Alumni, 1976.

Soejito, Irawan, Teknik Membuat UndangUndang, Ctk. Kelima, Jakarta: Pradnya Paramita, 1993.

Soeprapto, Maria Farida Indrati, IImu Perundang-Undangan, Dasar dan Pembentukannya, Yogyakarta: Kanisius, 1998.

Syarif, Amiroeddin, Perundang-Undangan, Dasar, Jenis, dan Teknik Membuatnya, Ctk. Kedua, Jakarta: Rineka Cipta, 1997.

Soehino, Hukum Tata Negara, Teknik Perundang-Undangan, Edisi Kedua, Ctk. Ketiga, Yogyakarta: Liberty, 2003. - Hukum Tata Negara, Penyusunan dan Penetapan Peraturan Daerah, Yogyakarta: Liberty, 1997. 
Peraturan Perundang-undangan

UUD 1945

Tap. MPR No. III/MPR/2000 tentang Sumber Hukum dan Tata Urutan Peraturan Perundang-undangan.
Tap No. 1/MPR/2003 tentang Peninjauan terhadap Materi dan Status Hukum Ketetapan MPRS dan MPR Tahun 1960-2003.

UU No. 24 Tahun 2003 tentang Mahkamah Konstitusi.

EOODE 